\title{
MODERATE ISLAM IN LOMBOK The Dialectic between Islam and Local Culture
}

\author{
Mutawali \\ IAIN Mataram - Indonesia | mutawali1963@gmail.com
}

\begin{abstract}
This study looks into the concept of moderate Islam; describes the distinctive formation of moderate Islam in Indonesia and dialectical phenomena between culture and religion in the Muslim community of the Lombok island. Grounded in qualitative method involving participative observation, interview, documentation and critical discourse analysis, this study reveals that the dialectics and dynamics between the shari'a texts with reality and local traditions in Lombok have brought about the concept of Islam Nusantara characterizing wasatiyyah (moderate), tawazun (balance), tasamub (tolerance), shura (priotizing dialogue), dan ittidal (justice). Islam Lombok illustrates the harmonious interfaith coexistence comprising pluralistic societies including diverse ethnicity, religion, and culture; and portrays Islam rabmatan lil 'Alamin (Islam as a mercy of the universe). Overall, this study suggests that the concept of moderate Islam could be seen in Lombok and might be applied in other communities in Indonesia.
\end{abstract}

Keywords: Moderate Muslims, acculturation, local tradition, Islam nusantara.

\section{Introduction}

This study is writer's reflection amid violence, which he terms as "The Theater of Violence", committed around the world, particularly in the mainstream Muslim countries or Islamic states. Worse is that such violence occurred close to the mosque of an-Nabawi (July 4, 2016), which would theologically unbelievably take place in such a holy area. This incident then meets its identical theory when it is linked with the Scott M. Thomas' statement, who states that radical thought and 
movement are usually driven by ideological and religious factors. However, such violence is often committed by radical parties. ${ }^{1}$

The term radicalism pertains to certain religious and political movements whose characteristics are much distinct from the mainstream practice. Radical movement strongly related to religion is actually associated with "a community of believers" rather than "body of belief." Nonetheless, the thesis or theory of Scott M. Thomas is rejected with reference to the context of Indonesia marked with plurality despite having Islam as the mainstream religion. The island of Lombok, as a part of Indonesia, with the majority of Muslim population and a myriad of different theologies, tribes, cultures, languages and etc., Muslims in the island can live a harmonious life with other non-muslim communities.

This research highlights the life of the people of Lombok which portrays pluralism, in which the majority Muslim can live together peacefully with the minority. It is an amazingly beautiful on the island that different symbols of religion can be in a perfect harmony, living side by side; even an Islamic community is framed by the surrounding Hindu community as portrayed in Bebidas village, Lombok. Another interesting fact on the island is that the tradition of perang topat (a multicultural food fight by means of rice-cakes), which takes place in Narmada. The peaceful interfaith coexistence is also illustrated in many different national and international events on the island such as MTQ XXVI 2016 (the twenty sixth national Quranic recitation contest). Therefore, the writer assumes that more diverse phenomena will allow the diversity itself to make a major contribution to the establishment of elegant and peaceful life.

In an effort to find out the patterns of understanding and the practices of moderate religion thriving in the muslim community on the island, the writer determines the type of research, method and approach used in this paper. This research is grounded in qualitative research underlying the Islamic themes with the topic of Islam Lombok-the miniature of Islam Nusantara. In qualitative research, the subject of the research acts as the research instrument to generate the

\footnotetext{
${ }^{1}$ Scott M. Thomas, The Global Resurgence of Religion and the Transformation of International Relation (New York: Palgrave Macmillan, 2005), p. 24.

2 Ibid., p. 24.
} 
data. ${ }^{\text {In }}$ garnering the qualitative data, observation, in-depth interview and documentation are employed. ${ }^{4}$

During the observation, the researcher interact with respective communities. Also, the researcher documents related data through various resources such as books, megazines, journals, newspapers, Internet, or other resourcesthat are relevant and closely related to the subject being studied. For the interview, the researcher employs unstructutured interview method by means of purposive sampling, ${ }^{5}$ which aims to find out the participants, namely any Islamic scholars and prominent figures of the community who are directly associated with the notion of moderate Islam.

To analyze the thought of moderate Islam, the researcher deploys critical discourse analysis which encompasses the connection between contexts such as background, situation, event and condition. ${ }^{6}$ To attain such objectives, the researcher employs the hermeneutics approach, which aims to gain understanding by interpreting certain texts or thoughts ${ }^{7}$, or to uncover certain assertions or thoughts. ${ }^{8}$ This approach asserts that certain ideologies do not suddenly present in an empty space; even the islamic thoughts are not independent from the situation and the development that grow in the community. ${ }^{9}$

\section{The Discourse of Moderate Islam}

The discourse pertaining to moderate Islam, like other Islamic paradigms, is not new, and is as a response to the rise of violence

${ }^{3}$ Imam Suprayogo and Tabroni, Metodologi Sosial Agama (Bandung: Rosdakarya, 2001), p. 134.

${ }^{4}$ Deddy Mulyana, Metodologi Penelitian Kualitatif (Bandung: Rosda Karya, 2001), pp. $162-$ 201.

5 Earl Babbie, The Practice of Social Research (New York: Wadsworth Publishing Company, 1988), p. 195.

${ }^{6}$ Eriyanto, Analisis Wacana Pengantar Analisis Teks Media (Yogyakarta: LKiS, 2001), pp.

7-8; Joachaim Wach, Imu Perbandingan Agama, trans. Djam'annuri (Jakarta: Rajawali Press, 1994), p. 83.

${ }^{7}$ Hasan Sutanto, Hermeneutik, Prinsip dan Metode Penafsiran al-Kitab (Malang: Seminari alKitab Asia Tenggara, 1989), p. 1.

8 Hidayat, "Arkoun dan Tradisi Hermeneutika," J. Hendrik Meuleman (ed.), Tradisi Kemodernan dan Meta Modernisme (Yogyakarta: LKiS, 1996), p. 24.

9 Karel Steenbrink, Metodologi Penelitian Agama Islam di Indonesia (Semarang: LP3M, 1985), p. 4. 
committed by two parties embracing either 'right' or 'left' ideologies. As a result, the notion of moderate Islam seems to be regarded as a beautiful means of practicing Islam in the global world which lies in between the affor mentioned parties, between the right and left groups. In the journal of al-Islam Din al-Wastiyah, it is stated that:

$$
\begin{aligned}
& \text { من الناحية اللغوية تمثل الوسطية المصدر الصناعي للفظ وسط الذي }
\end{aligned}
$$

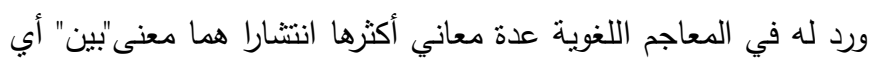

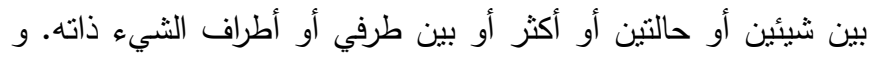

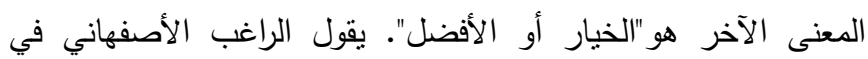

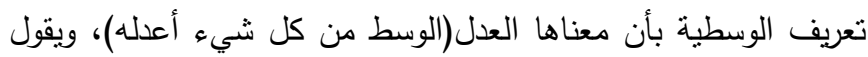

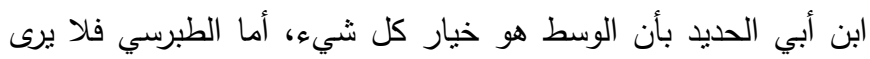

$$
\begin{aligned}
& \text { فرقا بين العدل و الخيار لأن معناهما واحد. }
\end{aligned}
$$

Epistemologically, moderate Islam is highlighted in the Qur'an because of entailing the dimension of "muqtasid", which means something in between that often preserves the balance, becomes a direction; and that is istiqamah (steadfastness), fair and straight forward, reflecting the Muslims as ummat wasata' describing 'khaira ummah. '11 Being moderate does not mean without having a clear attitude and righteousness in the religion, but avoiding excessive manner for being a Muslim (ghulul). The notion of contemporary moderate Islam is diametrically opposed to the manner of 'radical Islam' and 'Islamic fundamentalists', either of which tends to be conservative or secular featuring extremism, or is excessive in understanding and practicing the teachings of Islam. Wahbah al-Zuhaili argues that:

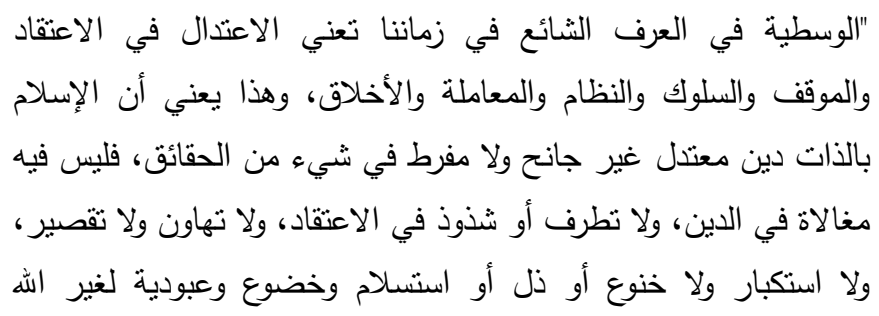

10 Al-Islām Dìn al-Wasatiyah wa al-I'tidal 'Alā Mada al-Zaman, p. 3

11 Ali Imran: 110 


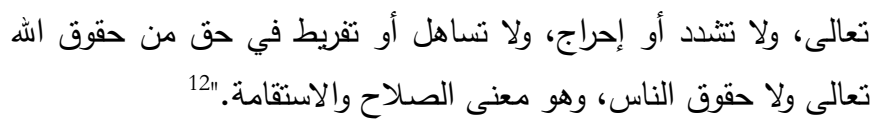

Yusuf al-Qardāwi, mentions that moderate Islam is a paradigm supported by the majority of Ulema (Islamic scholars) and has a special feature in Islam per se, which cannot be found in any other religions or cultures. ${ }^{13}$ The term (moderate) used when being adhered to the word Islam, both cannot be separated because this will turn in overlapping understanding. (1) Moderate Islam should be based on the belief that Islam is moderate, becomes the antithesis of extremism of previous religions, where the Jews are earthly and Christians are skyward. With this in mind, the existence of Islam will be an alternative to the two afore mentioned versions of extremism which encorporates the notion of earthly and skyward. (2) The modernization of Islam as elucidated above should be applied for understanding and practicing Islam by avoiding tatäruf (extremism).

This shows that Islam emphasizes the balance values featuring the logical thoughts to be actualised in everyday life. Therefore, any divergence in Islam should not cause segregation and disharmony within the community and the state, and the difference is a mercy, and plurality is something that Allah has purposefully created. This includes the difference in terms of science, opinions related to the truth of the holy book and its interpretation and any forms of its application. Consequently, fostering the understanding and practicing the moderate Islam in Indonesia are compulsory, even the nation is marked with myriad of plurality of different religions, cultures, geography and political states.

As a mental and behavioral paradigm, being moderate is not deviant from the teachings of Islam because it is highlighted in both the Qur'an and Hadith, or even as illustrated by the moral conducts of the previous generations in the history, the companions of the messanger and salaf al-Salih and the four Imams Mazhab (the four well known Scholars of Islamic Jurisprudence). The great companions of the prophet and Imam Madzhab used to have different interpretation or opinions with strong arguments, yet they never stated that theirs

\footnotetext{
12 Al-Islam Din al-Wasatiyah, p. 3

13 Yusuf Al-Qarḍawi, Mustaqbal al-Usuliyah al-Islamiyah (Damakus: al-Maktab al-Islami, 1998), pp. 19-37.
} 
was compeletely true or better than that of others, ${ }^{14}$ and they suggested that their followers follow the teachings from other resources such as the Qur'an and Hadith. ${ }^{15}$ Thinking and behaving moderately does not mean not to assert the truth or has no priciples. As a consequence, understanding Islam in moderate way, being not radical and liberal, will never hinder the spread of the mercy. The mercy of Islam is not confined to both the nobility of its teachings (internal) and to its politeness of preaching (external). Therefore, preaching should not be performed in a harsh way as it will only result in compulsion. Also, it is not possible for preaching by means of liberal attitude because this will eliminate many most essential sources of the divine grace for human beings.

\section{Moderate Islam: Distinction and Archipelago Pluralistic Reality}

Indonesia as the country with the level of complex variants and highly continuous rise of population of more than 200 million people and ranked the fourth after China, India, and America does not only bring about the economic and political benefits but also generate "viruses" that may harm the unity of the state. In addition, the geographical position of Indonesia which consists of a number of large and small islands with middleclass economy may also be a bitter table that potentially leads to conflict. However, the facts show that such diversities become the power of the state to sustain more graceful life, particularly interfaith coexistence in the country.

It is also admitted that Indonesia is not free from the riots between and within religions per se, but such problems can be tackled properly to avoid another bigger mass conflict as occurs in many countries in Middle East like Afghanistan, Syria, Iraq, and etc. The conflict resolution is the manifestation of the Indonesians being social and tolerant and their awareness of the importance of peaceful life. In this context, there are three possible potential dimensions that can be capitals to empower the thrive of moderate Islam in the Indonesia, namely culture, constitution and education.

14 Thaha Jabir Ulwani, Adab al-Ikhtilaf fi al-Islam (al-Wilayah al-Muttahidah alAmirikiyah: al-Ma'had al-'Alami Li al-Fikri al-Islami, 1087).

15 'Abd. Allah bin 'Abd. al-Muhsin Al-Ṭariqi, 'Abd. Allah bin 'Abd. al-Muhsin, alInkäaru fí Masa'il al-Ikbtilá (Riyadl: Makatbah al-Malik bin Fahd al-Wațaniyah, 1997), pp. 22-24. 
First, the cultural dimension: geopolitically, Indonesia flanked by two continents, Asia and Australia, and two oceans, the Pacific and Indian oceans, as well as having rich natural resources have become the main drivers of other countries since the beginning of the century $\mathrm{AD}$ for various purposes, which include religion, economy, trade, culture, and colonization. ${ }^{16}$ Historically, the penetration of Islam into Indonesia began through trading between the state and other Arabian states. Hence, Indonesia is easily recognized by the Arabian countries. This is because of its (1) geographically strategic position, lying between the international sea trade lanes from Middle East to China, and to American and Australian continents; (2) the fertility of land that produces food supply needed by other states such as spices, which subsequently moves into the political, educational, marital, artistic aspects, and such islamization is preached peacefully by the prominent preachers, muballigh, or ulemas in the country. Several efforts are made either through the process of acculturation or through the development of socio-religious structures of the community based local wisdom, such as the establishment and development of house of worship, and Islamic boarding schools as vehicles for Islamic preaching and community education.

By the same token, Islam in Indonesia is apparent in everyday encounters of the Indonesians, which includes its contribution to the characteristic and intellectual capacity building as evidenced in the resistence against the imperrialism and colonialism of other states for almost three and half centuries. This fact portrays that religion, however, when understood and adopted by certain communities, will generate certain tradition in the religion itself, in which Indonesia as a state has the tradition in its everyday religious ceremonies. ${ }^{17}$ Some experts identify that the strong influence and appreciation of the local culture on the religion as a process of adherence, to the conversion of Islam are brought the practices and traditions of the past religion. ${ }^{18}$

16 Azyumardi Azra, Islam in Shoutheast Asia; Tolerance and Radicalism, Paper presented at Miegunyah Public Lecture; The University of Melbourne, 06 April 2005; https://islamrahmah.com/tag/muslim-moderat-indonesia/ accessed on June 2, 2016

17 Tobroni, Relasi Kemanusiaan dalam Keberagamaan; Mengembangkan Etika Sosial melalui Pendidikan (Bandung: Karya Putra Darwati, 2012), p. 241.

18 Azyumardi Azra, Jaringan Global dan Lokal Islam Nusantara (Bandung: Mizan, 2002), p. 20. 
The harmonious relationship between Islam and local culture as well as its dialetics with the trading activities leads to the rise of nationalism, this is the real gift and mercy of the god, and perhaps the archipelago is designated to be the destination of the missions of divinity 'Ilahiyab' and of disambiguation 'risalah SAW', which means to be the mercy of the universe as a whole (rabmatan li al-'alamin). ${ }^{19}$

The above perspective presents strong understanding about the harmonious relation between mandkind and the values of Islam framed within the pluralistic societies, which cannot be detached from the reality that Islam can coexist with the socio-cultural reality among societies; historically, Islam has always been able to coexist with the local norms within the 'ibädah (spiritual) and mu'amalah (social) landscapes. ${ }^{20}$ In addition to that, the acceptence of Islam on the preArabic legal systems is a tribute to the fine tradition within the Arabian community in the light of the presence of moral virtues within the laws. ${ }^{21}$

The emergence of sufistic practices is another cultural tenet that contributes to the establishment of long-lasting tolerance and harmonious relation between social parties in the archipelago. The Sufis also play a pivotal role in the spread of Islam from Middle East, particularly to Southeast Asian nations including Indonesia, through the Tasawwuf tradition. By all accounts, the Sufism plays a key role because it encorporates Islamic tenets which maintain the perpetual practices of the traditional or local beliefs, so the early form of Islam is characterized by Sufism, which subsequently turns into some sufistic classes known as 'tariqa' (a school of sufism). It is worth mentioning that the mystical practices adhered especially to the Javanese and Indonesians in general, inherited from Hinduism and Buddhism, are the supporting factors that encourage them to readily embrace Islam through its Tasawwuf. Martin Van Bruinessen asserts that one factor that accelerates the penetration of Islam into the archipelagos that the

\footnotetext{
${ }^{19}$ Ahmad Syafii Maarif, Islam dalam Bingkai Keindonesiaan dan kemanusiaan Sebuab Refleksi Sejarah (Bandung: Ahmad Syafii Maarif Instutute and Mizan Pustaka, 2015), p. 46.

${ }^{20}$ Khalil 'Abd al-Karîm, Historisitas Syari'at Islam, trans. M. Faisol Fatawi (Yogyakarta: Pustaka Aif, 2003); Muhammad Salman Ghanim, Kritik Ortodoksi Tafsir Ayat Ibadah, Politik dan Feminisme, trans. Kamran Asad Irsyadi (Yogyakarta: LKiS, 2004); Imam al-

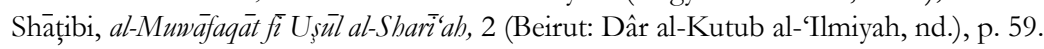
${ }^{21}$ Yusuf Hạmid al-'Ālami, al-Maqașid al-'Ammah li al-Shari' 'ab al-Isamiyyah (Vergenia: alMa`had al-'Ālami li al-Fikr al-Islami, 1993), pp. 92-93.
} 
influence of the cosmological and metaphysical teachings of Tasawwuf of Ibn al-'Arabi. His concept of Al-insan al kamil (the perfect man) mixed with the Indian and indigenous cosmologies as a spiritual legitimation is the potential for the kings at the time to legitimate the feudal system. The concept of the seventh divine emanation of Sufism is used by the sultanate of Buton Southeast Sulawesi to elucidate the existence of the social classes as found in the caste system in Hinduism. Another empirical evidence that can be accessed and maintained to date is the graves of the $W$ ali Songo (the nine revered Islamic saints in Java, Indonesia), which are often visited by many Muslims from different parts of Indonesia. For example, the mosque of Menara Kudus is believed as the masterpiece of Sunan Kudus (one of the nine Islamic saints), which protrays the acculturation of IslamHindu and the wisdom of Sufism as a means of preaching in a communicable way. ${ }^{22}$

The second factor that maintains the interfaith coexistence in Indonesia is the provision of the state constitution, the UUD 1945 and Pancasila, which guarantees that people have rights to own and run their own religious ceremonials or practices. As a consequence, all religious and educational institutions gain a great honor from the state. Hence, there is no room for other religious believers to assert that the state does not assure their existence. This also implies that Indonesia is not a secular state, nor a state affiliated to any religion," but a state, with reference to Al-Mawardi term, that guarantees "birasah al-din wa aldunya' (the afterlife and worldly matters), or a state that is based on the mutualism paradigm. ${ }^{23}$

The early establishment of the Indonesian state basic constitution 1945 and Pancasila served as the state's philosophical foundation faces an immense number of internal and external challenges. The former includes the challenge related to its muqaddimah particulary with respect to the seven words known as 'Piagam Jakarta' in Indonesian legal system, which states that the Republic of Indonesia is governed under the sovereignty of its people by the virtue of divinity and Shariah law. ${ }^{24}$

22 van Bruinessen, Martin, Kitab Kuning, Pesantren dan Tarekat (Yogyakarta: Gading Publishing, 2012), p. 226.

23 "The Modernity of Theocracy," in Juan Cole, Sacred Space and Holy War: The Politics, Culture and History of Shi' ite Islam (London and New York: I.B. Tauris, 2002).

${ }^{24}$ Suparman Usman, Hukum Islam; Asas-Asas dan Pengantar Studi Hukum Islam dalam Tata Hukum Indonesia (Jakarta: Gaya Media Pratama, 2001), p. 221. 
The debate over the proposal finally ends with the disposal of the disputed points in the initial part of the constituion in order to sustain the national stability and to avoid mass conflicts among its people. It is worthy of consideration that the agreement on the matter among the founding fathers and prominent figures of the country has become the most meaningful political consensus of the nation, a consensus that prioritizes national interests and brotherhood rather than that of individual, which is known as 'taqdim al-Kulliyah 'ala al-Juz'iyah' in the realm of 'ushul al-fiqh',25 as stated in the following principle:

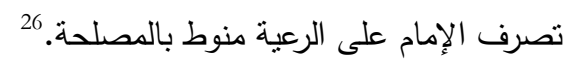

The third factor that mantains the coexistence of the pluralistic societies and religions in Indonesia is education. The important role that education has played in fostering the moderate ideologies in Indonesia is inevitable, either through formal or informal institutions such as Islamic boarding schools and etc. These Islamic institutions have been thriving well throughout different social classes in Indonesia. KH. Abdurrahman Wahid argues that Islamic boarding schools are a social sub-culture that have roles and functions that accord with the development, and they also have special characteristics as manifested in their physical and non-physical products. In their scientific tradition, to the Nabdliyyin (members of Nahdlatul Ulama), for example, the Islamic schools have become the corpus of Ablusunnah wal Jamaab (Aswaja) which are contextually dependent on either local, regional and global scope. The fundamental role of Aswaja on students is to provide them with Islamic ideologies that can coexist with the available cultural norms in Indonesia; on the other words, it contributes to the establishment of harmonious, elegant, and fair relation between cultures and the religion. Therefore, it can be said that Aswaja serves as a platform to the birth of moderate Islam, Islam that entails the characteristics such as 'tawazun' (balance), 'itidal' (temperance), 'tasamub' (tolerance) and 'tawasuth' (moderate). ${ }^{27}$

\footnotetext{
${ }^{25}$ Mutawali, JIL Menggugat, Digugat, (Mataram: Lembaga Kajian Islam dan Masyarakat (LKIM), IAIN Mataram), p. 265.

${ }^{26}$ Jalâl al-Dîn al-Suyûțî, al-Ashbâh wa al-Naz̧hâir fî̀ al-Furû' (Indonesia: Maktabah Dâr Ihyâ' al-Kutub al-'Arabiyah, nd.)

27 Sa'id Aqil Siraj, Tasawnf Sebagai Kritik Sosial Mengedepankan Islam Sebagai Inspirasi, Bukan Aspirasi (Jakarta: SAS Foundation and LTN PB NU, 2012), pp. 424-426.
} 
In addition to that, Gus Dur terms the concept above as localizing Islam, an effort to preserve the long--established assimilation and acculturation process of Islamic values with the local cultures in Indonesia. He states that Islam takes into account the local needs for constructing Islamic laws without depriving of their essence-- it does not abandon the norms for sake of the culture but tap into them to facilitate the needs of the culture with reference to various understandings of nash (literal meaning of Qur'an or Hadith) and openness to the principles of usül fiqh and qaidah fiqh. ${ }^{28}$

The role of education can be optimized to set a deradicalization agenda, and Islamic institutions along with other educational institutions can play such a role, so that the Islamic outlook in Indonesia remains friendly, tolerant, moderate, yet it still gains fame worldwide.

The elucidation above clearly illustrates the characteristics of moderate Islam, ${ }^{29}$ which has historically been profilerating throughout the archipelago. These moderate values are apparent within the legal and democratic system of Indonesia: respect for gender equality, ${ }^{30}$ minority, tribe, religion and its opposition to the radical Islam and terorrism.

\section{Lombok: Home of Pluralistic Culture}

The global spread of Islam has its special characteristics and uniqueness in comparison to Islam in the Arabic world. It is understandable that every religion including Islam is not contextually independent. Islam is not born in free laden cultural contexts. There is always a perpetually dynamic influence between Islam and reality. ${ }^{31}$

Lombok is one of the small islands streching from the Western to Eastern part Indonesia, which geographically lies within the province of NTB (West Nusa Tenggara). This province comprises two main

28 Abdurrahman Wahid, Pergulatan Negara, Agama, dan Kebudayaan (Jakarta: Desantara, 2001), p. 111.

29 Angel Rabasa, Building Networks Muslim Moderate, Center For Middle East Public Policy, p. 66

30 Abdullahi An-Naim, "Public Forum on Human Rights, Religion \& Secularism," notes by Siew Foong on speech delivered by Abdullahi An-Naim, National Evangelical Christian Fellowship Malaysia, January 18, 2003.

31 Masnun Thahir, "Pergumulan Hukum Islam dan Budaya Sasak: Mengarifi Fiqih Islam Wetu Telu,” Jurnal ISTIQRO', Volume 06, 01 (2007), p. 174. 
islands, Sumbawa and Lombok, which pertain to Kepulauan Sunda Kecil (Southeastern Islands) including the islands lying from the eastern part of Java island, Bali to Timor islands. ${ }^{32}$

The indigenous Sasak is the mainstream community across the province of NTB based on the archeological evidence in 1977. The indigenous people have dwelled in Lombok since the fourth century ago or about 1600, who have established their own culture. The Sasak community comprises more than $90 \%$ of the island total pupulation with the rests of ethnics including Baliness, Javaness, Arabian, Chinese etc. In addition to that, the island is home to a myriad of languages, religions, and religous ideologies. Precisely, the ethnics Sasak, Arabian and Bugis embrace Islam, while others such as Bali and Chinese are respectively Hindus and Christians or Konghucu.

Research by Van Erde and Bousquet reveals that Lombok is home to pluralistic culture. In the community of Sasak, they are three different sub-religions, namely Sasak Boda, Waktu Lima and Waktu Telu. The former is assumed to be the original belief of the community. Sasak Boda believe in the power of spirit-they worship spirits of their ancestors from various local gods. ${ }^{33}$

\section{The Dialectic of Islam and Local Culture}

The dialectic of Islam and local culture is apparent in the rituals of the Wetu Telu religious cermonials. The goup possesses some religious ceremonies that portray the life circle known as 'gawe urip', which includes the life span of human beings from the birth to the death, namely (1) Buang $A u$ (birth ceremony), the disposal of charcoal ceremony by a Belian (traditional healer) after assisting a birth. This ceremony is conducted a week after giving birth. At the same time, the parents denouce the proper name of their child after consulting with some local prominent figures of Islamic scholars; (2) Ngurisang (hair cut) is the second birth ceremony. This is held after the child is about 1 to 7 years old. This religious event is of paramount importance because it indicates that the child has been regarded as a muslim as opposed to Boda, which means non-muslim believer; (3) Ngitanang (circumcision), it is proceeded after the child is reaching 3 to 10 years. Like the

\footnotetext{
32 Depdikbud RI, Adat Istiadat Nusa Tenggara Barat (Jakarta: Depdikbud RI, 1997), pp. $11-12$

33 Erni Budiawanti, Islam Waktu Telu Versus Islam Waktu Lima (Yogyakarta: LKIS, 2000), p. 8.
} 
aforementioned ceremonies, Ngitanang indicates that the child is already islamised as otherwise the child remains Boda; (4) Merosok (leveling teeth), which indicates that the transition phase of the child from young to an adolescent. In this ceremony, muslim scholars or local figures soften the teeth of the male and female offsprings lying on a Berugak (shelter); and (5) merari/Mulang (elopement) and Metikah (marriage). Other religious rituals related to death are called 'gawe pati' (ritual of death and after death). This is held from nusur tanah (burial), nelung (the third day after the death), mituk (the seventh day after the death), nyiwak (the ninth day after the death), matangpuluh ( the fourty day after the death), nyatus (a hundred day after the death) and nyiu (the thousand day after the death).

In the light of the above description, it can be understood that religion and local culture are two different entities; however, both should not be disputed, between the two is an unavoidable coexistence. The tradition of Waktu Telu remains practiced to date despite having experienced several changes due to the continuous dialectic between the people, tradition, and time, which illustrates the dynamic existence of local Islam in Lombok.

Besides embracing Sasak Boda and Islam Waktu Telu, the indigenous people also embrace 'Waktu Lima'. For the group, it is obliged that all of the followers practice all the pillars of Islam including praying for five times every day and doing other religous practices. Therefore, they argue that the followers of Islam Waktu Telu only pray three times a day, namely Maghrib (Evening prayer), Isya (night prayer), and Subuh (down time prayer).' In addition, they also assume that Islam Waktu Telu does not practice daily fasting during Ramadhan, in which they only fast three times, at the beginning, middle and the end of the month. ${ }^{34}$

Subsequently, the majority of the indigenous community on the island embraces Islam Waktu Lima, which remains the majority group to date. This occurs due to the continuous preaching of some Islamic scholars towards the community of $W a k t u$ Telu. These Islamic figures include TGKH. Muhammad Zainuddin Abdul Madjid (the founding father of Nahdhatul Wathan), TGH. Mutawalli (the founding father of Darul Yatama wa al-Masakin islamic boarding school, TGH. Shafwan al-Hakim,

\footnotetext{
34 Muhammad Noor et al., Visi Kebangsaan Religius TGKH M. Zainuddin Abdul Madjid, (Jakarta: Ponpes NW Jakarta and LPA, 2014), p. 97.
} 
(the head of Nurul Hakim Islamic boarding school), and TGH. Hazmi Hazmar, (the head of Maraqit Ta'limat Islamic boarding school).

It is worth mentioning that the charismatic moderate muslim cleric, TGKH. Zainuddin Abdul Madjid initially declared and fostered the moderate thoughts through his Islamic organisation, Nadlatul Wathan (NW) on July 15th March 1953. The inital forms of this organisation were Diniyyah Islamiyah on the August 15th 1937 and Nabdaltul Banat Diniyyah Islamiyah (NBDI). ${ }^{35}$

Since the beginning, NWDI and NW are the mass Islamic organisations embracing the concept of Wasathiyyah Ablus Sunnah wa alJamaah 'ala Madz̧hab Imam al-Syafi'i, which aim to uphold the Islamic principles within Islam and muslims. The nobelty of Islam Indonesia inspires TGKH. Zainuddin Abdul Madjid to establish the organisation 'the rising of the state' (nabdlatul wathan). For him, NW has two philosophical meanings, namely establishing Islam and the Indonesian state simultaneously; and building Islam and Muslims as well as the Indonesian Republic. His efforts continue to sustain the independence of Indonesia either through his preaching, education, and sociopolitical practices. These objectives are passed over and continued by his organisation to date. The principle of moderate Islam is a framework for actualising Islam rabmatan lil 'alamin, Islam as a mecry for the whole universe, and the integration of Indonesian Islam. ${ }^{36}$

The indigenous people of Sasak as the mainstream ethnic embracing Islam indrectly represent the island of Lombok as a religious community. The inevitable fact which supports the notion above is the public use of the term 'pulau seribu masjid' (the island of thousand mosques) adhered to the island. The data from the ministry of religous affairs shows that the island are about 3151 mosques available. In addition to that, the spirituality is apparent as portrayed by the provision of many groups doing Islamic studies, lecture and other religious practices. In terms of education, it is illustrated by the availability of some Islamic boarding schools and other Islamic institutions. These phenomena give profound impacts on the development of their spiritual intelligence based on the moderate values of Islamic teachings.

\footnotetext{
35 Ibid., p. 164.

36 Azyumardi Azra, "Islam Rahmatan Lil 'Alamin dan Wawasan Kebangsaan: Perspektif TGKH M. Zainuddin Abdul Madjid (1904-1997) dan NW," Paper presented at Muktamar XIII NW Nurul Haramain, Lombok Barat, NTB 7-9 August 2016.
} 
In the educational landscape, the Sasak people are very much interested in escalating their knowledge and education, which is illustrated by the provision of many formal and informal education institutions, particularly religous education.

Table 1. The Data of Islamic Boarding School in Lombok

\begin{tabular}{ll}
\hline \multicolumn{1}{c}{ City and regency } & Number of Islamic schools \\
\hline Mataram city & 16 \\
West Lombok Regency & 60 \\
Central Lombok Regency & 51 \\
East Lombok Regency & 71 \\
North Lombok Regency & 10 \\
\hline Total & $\mathbf{2 0 8}$ \\
\hline
\end{tabular}

Source: Data of Islamic boarding schools taken from the provincial religious affairs of NTB in 2000.

In relation to the development of Tariqa, its arrival and spread in Lombok do not adopt a rigid preaching system. The implementation of Tariqa teachings more strongly correspond to the loose interpretation of Tasawnf principles, as highlighted in the fourteenth lyric of Tembang Dangdang (a classical vocal music), taken from the Cilinaya manuscript, as the followings:

Banjur dateng angin topan gelis, si kesukaq Allah si kuasa

(Suddenly there comes a blowing tornado due to the fate of the almighty God)

Bijan Datu Daba nane, takelepan ya batur, siq anginna no nengka glis

(The daughter of King Daha is then taken to the sky by the wind very quickly)

Kaget Datu nyreminang, pada momot ya banjur

(The king can not do anything just watching at what is happening to his daughter)

Datu bini, Datu Lanang nyengoq bija

(The king and queen are just looking at the disappearance of their daughter)

Ngawang ngawang Neneq bini

(The daughter is drifting away)

Datu nongaq langit dowang.

(The king is just looking at the sky) 
In addition, in Tembang Sinom in the fourteenth lyric of Rengganis manuscript, it is highlighted as the followings:

Goyo Taruna ndeqna gila, Siq toaq bajerik tarik

(Even the young will not be madly crazy; the adults too

return)

Kyai pada badoa, Guru Tuan gurik tahlil

(Muslim scholars pray; Islamic clerics read Tahlilan)

Sangkaq lueq Guru Kyai lupaq tarekat Tuan Guru

(Because of the provision of many teachers, Muslim scholars

abandon the teachings of Islamic clerics)

Si angena kambelisan, pada mele bawa diriq

(Because of the unstable faith, all want to show off)

Mupakat mele pada engkah sembahyang.

(Together leaving off five times prayers) ${ }^{37}$

It is clear that in the lyrics of the Cilinaya manuscript the teachings of Tasawnf embody more philosophical values than its systematic teachings. This diverse form of Tasawnf appears as a result of the its historical spread that undergoes the acculturation process between its spiritual components and surrounding Javaness culture, the mystical beliefs. These beliefs are inherited from Budha and Hindu before the arrival of Islam. ${ }^{38}$

The interconnection between the Jawi and Kawi manuscripts and interpretation of Islam, including Tasawuf and Tariqa , can be seen in the following manuscripts: ${ }^{39}$

Table 2. Interconnection between Jawi and Kawi Manuscripts and Interpretation of Islam

\begin{tabular}{llll}
\hline Name/Manuscript Title & Number & \multicolumn{1}{c}{ Content } & Category \\
\hline Abu Bakar & 2 & Stories of prophets & Humanity \\
Adi Parwa & 1 & - & - \\
Agama & 2 & Islamic teachings & Religion \\
Agama & 1 & The teachigs of & Religion \\
& & Buddha and Hindu & \\
\hline
\end{tabular}

${ }^{37}$ Departemen Pendidikan dan Kebudayaan, Bunga Rampai Kutipan Naskab Lama dan Aspek Pengetabuannya (Mataram: Museum Negeri NTB, 1991), p. 37, p. 71.

38 Abdul Quddus and Lalu Muhammad Ariadi, "Gerakan Tarekat dan Pertumbuhan Budaya Berfilosofi di Lombok," Jurnal Teosofi Vol 1 (2015).

${ }^{39}$ Suripan Sadi Hutomo, Filologi Lisan (Jakarta: CV Lautan Rezeki, 1999), p. 6. 


\begin{tabular}{|c|c|c|c|}
\hline Name/Manuscript Title & Number & Content & Category \\
\hline Agama Hindu & 2 & $\begin{array}{l}\text { The teachings of } \\
\text { Hindu }\end{array}$ & Religion \\
\hline Agama Islam & 20 & $\begin{array}{l}\text { The teachings of } \\
\text { Islam }\end{array}$ & Religion \\
\hline Ajar Wali & 2 & Noble Story & Humanity \\
\hline Aji Sang Hyang Ayu & 1 & Mantra & Literature \\
\hline Aji Sang Hyang Bayu & 1 & Mantra & Literature \\
\hline Aji Serandil & 1 & Tale & Literature \\
\hline Akherat & 1 & $\begin{array}{l}\text { The teachings of } \\
\text { Islam }\end{array}$ & Religion \\
\hline Akhlak & 1 & $\begin{array}{l}\text { Local and religious } \\
\text { values }\end{array}$ & Religion \\
\hline Ala Ayuning Dewasa & 1 & Prophet & Humanity \\
\hline Alam Kudus & 1 & Sufi order & Spirituality \\
\hline Amir Hamsyah & 90 & Noble Story & Humanity \\
\hline $\begin{array}{l}\text { Amir Hamsyah ing Ngutus } \\
\text { Mara ing Nagareng Yunan }\end{array}$ & 1 & Noble Story & Humanity \\
\hline Ana Kidung & 7 & The story of Adam & $\begin{array}{l}\text { Humanity } \\
\text { and Sufi } \\
\text { order }\end{array}$ \\
\hline Andanigar & 2 & Noble story & Humanity \\
\hline Asmara Kandi & 1 & Noble story & Humanity \\
\hline Babad Lombok & 1 & Chronical & History \\
\hline Babad Tuan Besar & 1 & Chronical & History \\
\hline Babad Lombok & 1 & Chronical & History \\
\hline Badik Walam & 4 & Noble Story & Humanity \\
\hline Bancangah Batu Dendeng & 1 & Bancangah & History \\
\hline Badik Walam & 4 & Noble story & Humanity \\
\hline Bancangah Batu Dendeng & 1 & Bancangah & History \\
\hline Dalang Jati & 2 & Philosophy & Philosophy \\
\hline Doyan Neda & 4 & Tale & Literature \\
\hline Jatiswara & 46 & Theology & Philosophy \\
\hline Kabar Melayu & 3 & Noble story & Humanity \\
\hline Kitab Perukunan & 1 & $\begin{array}{l}\text { The teachings of } \\
\text { Islam and Tasawuf }\end{array}$ & Religion \\
\hline Manusia Jati & 1 & $\begin{array}{l}\text { Theology and } \\
\text { Tasawuf }\end{array}$ & Philosophy \\
\hline
\end{tabular}




\begin{tabular}{lllr}
\hline Name/Manuscript Title & Number & Content & Category \\
\hline Insan Kamil & 2 & $\begin{array}{l}\text { Theology and } \\
\text { Tasawuf }\end{array}$ & Philosophy \\
\hline
\end{tabular}

The afore mentioned facts have given positive impacts on the establishment of peaceful and elegant relation among individuals and communities. This relation is reflected in everyday life of Sasak people as illustrated in Bebidas village in the city of Mataram, a village comprising around 700 families with one commune leader and four neighbourhood leaders.

The researcher's probe into the village shows that it is located in the center of Hindus community, which surrounds the village in the Eastern, Western, Northern and Southern part. This illustrates that the village truly lies in the center of Hindus community, which reflects the factual existence of interfaith coexistence between the two religious groups.

When the researcher tries to understand the ideal phenomenon by interviewing a muslim intellectual, Husnul Hathari, he describes that the existence of Bebidas village is undeniably true. However, they can live a harmonious life. There has never been any clash between the two parties since their existence. Their social-religious interaction is so beautiful that they visit each other when there is a socio-religious event-even they marry each other. If any clash takes place, it is only influenced by external factors; it can be immediately overcome. ${ }^{40}$

Furthermore, when the researcher questions why their lives are more harmonious, he says that it is due to the fact that the muslims in the village study Islam from Sekarbela (another Muslim village which is about two kilometers from Bebidas), which, according to him, fosters the teachings of NU, moderate Islam. He adds that NU with its moderate teachings brings about harmonious and peaceful nuance, particularly within the pluralistic societies. He continues that the people in Bebidas are close to the villagers from Sekarbela, whose professions are mainly trading. In business, they do need convenient and peaceful atmosphere. This is what also triggers the harmonious bond between the Muslims and Hindus and other surrounding religious believers.

${ }^{40}$ Interview with Husnul Khatari, June 14, 2016 
Recently, moderate Muslims in Lombok perceptually tolerate and respect the minority groups on the island. This situation is depicted in the XXVI MTQ (national Qur'anic competition) from 27 July to 7 August 2016 on the island. In his speech at the event, the governor of the province, the grandchild of the founding father of Nahdlatul Wathan, says that many local Hindus guards have much contributed to the success of this national Islamic festival. They also take part in safeguarding the preparation and implementation of the event on Lombok NTB. ${ }^{41}$

In his opening speech, the governor also speaks out the contribution of some representatives of the Tionghoa who also actively participate in the event, even they propose themselves to also play role in the festival.

The Islamic mass organizations in Lombok also campaign for Islam Nusantara. The moderate values of Islam is introduced through tolerance and high acculturation process. The leader of NU NTB argues that Islam Nusantara proliferates through the networking of Ahlussunab wal Jamaah. They deeply learn the concept and directly immerse in the society. Islam Nusantara is an alternative to the civilization; it can be assimilated with the social lives of the society. The dialectic between Islam and culture has generated the emergence of new variant of Islam, which differs from Islam in Arabian countries and other places $^{42}$.

The chief of FKUB (the interfaith dialogue association) of NTB sheds more light on the harmonious relation between Islam and minority groups in the province. He says that the peaceful interfaith connection among the religious believers in Lombok has been long established, and they also work together and help each other in everyday encounters. Some minor conflicts between the religious groups are solved through dialogic discussions. ${ }^{43}$

In relation to the potential of religious conflicts in Lombok, he states that several riots related to religious issues, such as the building of worshiping houses, rituals, and religious celebration, have indeed occurred. However, they can be resolved due to a myriad of factors including religious teachings, local wisdom, the roles of some Muslim

\footnotetext{
${ }^{41}$ Gubernur NTB, Pidato pembukaan MTQ Nasional XXVI di Lombok, NTB

42 Interview with TGH. Taqiyuddin, Chairman of PWNU NTB, July 25, 2016

${ }^{43}$ Interview with TGH. Sahdan Ilyas, Chairman of FKUB NTB, July 7, 2016
} 
clerics or scholars, and prominent figures of local custom as well as the governments themselves, all of which play a key role in cooling down the situations. ${ }^{44}$

In response to the radical Islamic movement and terrors in Indonesia, particularly Bima, the chief of Muhammadiyah mass organsization of NTB, Palahuddin, argues that all the religious believers including Muslims in Lombok are tolerant, moderate and open. However, because of their great number, it cannot be denied that there are indeed some extremist groups, but they remain minority. Regarding the assumption that Indonesia as a place where the Islamic extremist thrive, to him, it derives from the transnational groups such as ISIS, Wahhabi, and so forth. .5

In the context if dialectic between Islam and local culture in Lombok, the secretary of IAIH NW NTB argues that as the last divine religion, Islam is believed to fit every period of time and place, which means the religion will continue to coexist with dynamic and pluralistic societies and cultures until the end of the time. The looseness of Islamic jurisprudence is one among the many factors that affords Islam in Lombok to be able to live peacefully together with other manifold ethnics and religions. ${ }^{46}$

\section{Moderate Islam Lombok and the Unique Variant of Islam}

The acculturation between Islam and the local culture, as the writer has elucidated, eventually turns in a unique variant of Islam, which Azra terms as distinction, like Javenese Islam, Sasaknese, Minangese, and Sundanese Islam. The aforementioned variants of Islam do not deviate from the principles or the essence of Islamic teachings, instead they acculturate with local cultures. ${ }^{47}$

Sasaknese Islam is one variant of Islam in Indonesia which is formed as a result of the dealectic process between Islam and the local culture in Lombok. Such a process in turn generates a special unique Islam underlying Lombok traditions assimilated with the Islamic

\footnotetext{
${ }^{44}$ Interview with TGH. Sahdan Ilyas, Chairman of FKUB NTB, July 7, 2016

45 Interview with H. Palahuddin, Chairman of PW Muhammadiyah NTB, July 27, 2016

46 Interview with TGH. Jamiludin, Secretary of IAIH NW NTB, July 29, 2016

47 Paisun, "Dinamika Islam Kultural:Studi Atas Dialektika Islam Dan Budaya Lokal Madura," El Harakah Vol. 12, No.2 (2010).
} 
values. Subsequently, Islam and the traditions of Lombok have been united and cannot be separated yet can be differentiated.

Geographically and demographically, the ethnics and socioreligions in Lombok are bordered by two provinces: Bali in the west and East Nusa Tenggara in the east. The mainstream religion embraced by the Baliness is Hindu, while the latter is the majority of Christian. Despite this fact, the interfaith relation, socio-religion, among the believers in Lombok remains harmonious and peaceful. This is illustrated by the fact that the everyday life of the muslims shows friendliness and openness to Hindus community despite the majority of the latter group's having strong bond with Baliness Hindus. It also applies to Christians who have familial relation with Christians in East Nusa Tenggara.

The spread of Islam to the southeast Asia, particularly Indonesia, is through the process of acculturation. The implication of this approach is the assimilation of cultural values into the religion, or the religion can be a legitimation of the culture. The dialectic process between the two elements is as a logical consequence of the divine religion that exists within the community. ${ }^{48}$

The provision of the dialectic between Islam and local culture in Lombok has brought about the openness and tolerance towards any culture and religions penetrating into the island. The open and tolerant concept of Islam Nusantara in the island, to Azra, makes it distinctive from the mainstream outlook of Islam in Middle East. This pluralistic outlook, according to Gusdur, is called 'pribumisasi Islam' (localizing Islam), which means that Islam as the divine religion is accommodated by local cultures featuring their own characteristics. This concept derives from the teachings of the nine Islamic saints in the island of Java between 15th and 16th centuries. They successfully marry the Islamic and cultural values. Such way generates the Islamic variant that characterizes Indonesian Islam or Islam Nusantara. This creative way of preaching establishes Islam that is not textual, such as the one in Arabian countries. There is no any Arabian culture adhered to the early penetration of Islam into the archipelago.

The history shows that Islam in Lombok is typical of Sufism, which is acculturated with the mystical beliefs in the Javanese culture and the strength of spiritual elements found in the culture of Lombok.

48 Azyumardi Azra, Jaringan Ulama Timur Tengah dan Kepulauan Nusantara Abad XVII dan XVIII (Bandung: Rosda Karya, 1999). 
This gives birth to the tolerant Islam. The harmonious interfaith relation in Lombok has generated peace and grace among the religious believers in the island. Islam in Indonesia is a local Islam spread by the $W$ ali Songo and its followers by means of cultural transformation in the community; Islam and culture are not placed equally to each other, but set within a creative dialogic frame. This approach results in two assimilated components, namely religion and local culture.This mixture is the one that generates Islamic traditions which are still practiced nowdays in the community of Islamic traditions in Indonesia.

The acculturation of values of Hajj with the sprituality found in the Sasak tradition shows that Hajj is not a mere symbol of Islam but also a source of unity of muslims. It also conveys the religious messages and moral values. These messages are prevalent in the rituals practiced during the Hajj, whose aims are to empower muslims' understanging about the oneness of god, respect each other (tasamub), and maintain harmonious relation and balance between the nature, god and humans (tawä̌run). ${ }^{49}$

In Lombok, to the Hajj pilgrims, the unversal meanings of Hajj such as monotheism, affection, social solidarity, and honor to the nature and social justice are all embedded in the Sasak comunity, the indigenious people of Lombok. Through Hajj pilgrimage, Islam becomes the primordial identity of Sasaknese and their religious principles.

Islam Pribumi (Local Islam) as opposed to that of Arabian sorts has three characteristics. First, it is contextually dependent, which means Islam is understood based on the context. The shift in settings becomes the key to interpretinng its teachings. With this regard, Islam will undergo changes as a response to the time shift. Second, local Islam is progressive, which means that it positively responds to the advancement through intense creativity, instead of regarding the shift as a threat. Third, local Islam is characterized by freedom, which means that it can be an alternative to humanitarian problems regardless of the differences related to religions and ethnics. In this regard, Islam is not rigid in response to the social reality in the community that usually undergoes changes.

${ }^{49}$ Lalu Muhammad Ariadi, Haji Sasak; Sebuah Potret Dialektika Haji dengan Kebudayaan Lokal (Jakarta: Impressa Publishing, 2013) 
With this regard, Hamami Zada argues that the local Islam intends to free itself from any puritan doctrines and authenticity. It also aims to sustain the local wisdom without depriving of the essence of Islamic teachings. Therefore, local Islam is an Islamic variant whose ideology is culturally based, which takes into account local identity. This is what makes Islam penetrates into the archipelago without undermining the local traditions. Within this frame, there will no be any radicalism underpinned by extremist groups, which has long become a threat to the actualization of peace. ${ }^{50}$

\section{Conclusion}

There are three dimensions that encourage the penetration of moderate Islam in Indonesia, namely culture, constitution and education. The acculturation process of culture and the development of socio-religious sturcture based local wisdom have facilitated the notion of respect or honor towards the pre-existing traditions. With regard to the second dimension, UUD 1945 and Pancasila secure the unity of Indonesian state with its pluralistic societies. In addition, education contibutes to the formation of moderate ideology in Indonesia, like islamic boarding school as a feature of islamic education in Indonesia comprising the various social classes since long time ago.

Moderate Muslims in Lombok have successfully implemented the essence of Islamic teachings in the archipelago as highlighted in everyday harmonious encounters of the community in the island. Islam Nusantara based on the Islamic norms which have been enherited from Sufis and Islamic scholars is characterized by and communic able with local wisdom through the process of selection, adaptattion and acculturation. With its moderate principle characterized by tawassut (middle way), tawazun (balance) and i'tidal (explicitness), it is expected that Islam Lombok can contribute as moderate muslims, who are fair, open, and dynamic; as mulims who can mediate between radicalism and terrorism in terms of socio-religious life. In addition, the concept of Islam Nusantara should be perceived as an alternative model to the development of international civilization amid the global threats to the existence pluralistic societies.[]

\footnotetext{
50 Hamami Zada, Islam Radikal, Pergulatan Ormas-Ormas Islam Garis Keras di Indonesia (Jakarta: Teraju, 2002).
} 


\section{References}

\section{Books and Articles}

Al-'Asymāwi, Muhammad Sa'id. al-Islam al-Siyasi. Cairo: Madbuly alṢaghirir, 1996.

-------. al-Sharīah al-Islamiyyah wa al-Qanun al-Misri. Cairo: Madbuli alȘaghir, 1988.

Ariadi, Lalu Muhammad. Haji Sasak; Sebuah Potret Dialektika Haji dengan Kebudayaan Lokal. Jakarta: Impressa Publishing, 2013

Al-Shāțibi, Imam. al-Muwāfaqăt $\overline{f i}$ Uşul al-Shari'ah, 2. Beirut: Dâr alKutub al-'Ilmiyah, nd.

Al-Qarḍawi, Yusuf. Mustaqbal al-U.suliyah al-Islamiyah. Damasks: alMaktab al-Islami, 1998.

Al-Ṭariqi, 'Abd. Allah bin 'Abd. al-Muhsin. al-Inkarm $\overline{f i}$ Masa'il alIkhtilaf. Riyadl: Makatbah al-Malik bin Fahd al-Wathaniyah, 1997.

An-Naim, Abdullahi. "Public Forum on Human Rights, Religion \& Secularism," National Evangelical Christian Fellowship Malaysia, January 18, 2003.

Azra, Azyumardi. "Islam in Shoutheast Asia; Tolerance and Radicalism." Paper presented at Miegunyah Public Lecture; The University of Melbourne, 06 April 2005

---------. Jaringan Ulama Timur Tengah dan Kepulauan Nusantara Abad XVII dan XVIII. Bandung: Remaja Rosda Karya, 1999

---------. "Islam Rahmatan Lil 'Alamin dan Wawasan Kebangsaan: Perspektif TGKH M. Zainuddin Abdul Madjid (1904-1997) Dan NW." Muktamar XIII NW Nurul Haramain, NTB 7-9 Agustus 2016

---------. Jaringan Global dan Lokal Islam Nusantara. Bandung: Mizan, 2002.

Budiawanti, Erni. Islam Waktu Telu Versus Islam Waktu Lima. Yogyakarta, LKIS, 2000.

Cole, Juan. Sacred Space and Holy War: The Politics, Culture and History of Shi' ite Islam. London and New York: I.B. Tauris, 2002. 
Dahlan, Abdul Aziz. "Pembelaan Terhadap Wahdat al-Wujud: Tasawwuf Syamsuddin al-Sumartani." Ulumul Qur'an, Vol. III, No. 3, 1992.

Gellner, Ernest. Muslim Society. Cambridge: Cambridge University Press, 1981.

Ghanim, Muhammad Salman. Kritik Ortodoksi Tafsir Ayat Ibadab, Politike dan Feminisme, trans. Kamran Asad Irsyadi. Yogyakarta: LKiS, 2004.

Hutomo, Suripan Sadi. Filologi Lisan. Jakarta: CV Lautan Rezeki, 1999.

Ma'arif, Syafii. Islam dalam Bingkai Keindonesiaan dan kemanusiaan Sebuah Refleksi Sejarah. Bandung: Mizan Pustaka, 2015.

Mutawali, JIL Menggugat, Digugat. Mataram: Lembaga Kajian Islam dan Masyarakat (LKIM), IAIN Mataram.

Noor, Muhammad et al. Visi Kebangsaan Religius TGKH Mubammad Zainuddin Abdul Madjid. Jakarta: Ponpes NW Jakarta and LPA, 2014.

Paisun. "Dinamika Islam Kultural:Studi Atas Dialektika Islam Dan Budaya Lokal Madura.” El Harakah Vol. 12, No. 2 (2010).

Quddus, Abdul and Lalu Muhammad Ariadi. "Gerakan Tarekat dan Pertumbuhan Budaya Berfilosofi di Lombok." Teosofi, Vol. 1 (2015).

Siraj, Sa’id Aqil. Tasawnf Sebagai Kritik Sosial Mengedepankan Islam Sebagai Inspirasi, Bukan Aspirasi. Jakarta: SAS Foundation and LTN PB NU, 2012.

Thahir, Masnun. "Pergumulan Hukum Islam dan Budaya Sasak: Mengarifi Fiqih Islam Wetu Telu." ISTIQRO', Volume 06, 01 (2007).

Thomas, Scott M. The Global Resurgence of Religion and The Transformation of International Relation. New York: Palgrave Macmillan, 2005.

Tobroni, Relasi Kemanusiaan dalam Keberagamaan. Bandung: Karya Putra Darwati, 2012.

Ulwani, Thaha Jabir. Adab al-Ikbtilaf fi al-Islam. al-Wilayah alMuttahidah al-Amirikiyah: al-Ma'had al-'Alami Li al-Fikri alIslami, 1087. 
Mutawali

Usman, Suparman. Hukum Islam Asas-Asas dan Pengantar Studi Hukum Islam dalam Tata Hukum Indonesia. Jakarta: Gaya Media Pratama, 2001.

van Bruinessen, Martin. Kitab Kuning, Pesantren dan Tarekat. Yogyakarta: Gading Publishing, 2012.

Wahid, Abdurrahman. Pergulatan Negara, Agama, dan Kebudayaan. Jakarta: Desantara, 2001.

Wahyudi, Chafid. Tipologi Islam Moderat dan Puritan: Pemikiran Khaled $M$. Abou El-Fadl. Teosofi Vo1, 1 (2011).

Yüsuf Hamid al-'Ālami. al-Maqaşid al-'Ammah li al-Shari' ah al-Isamiyyah. Vergenia: al-Ma‘had al-'Ālami li al-Fikr al-Islami, 1993.

Zada, Hamami. Islam Radikal, Pergulatan Ormas-Ormas Islam Garis Keras di Indonesia. Jakarta: Teraju, 2002.

\section{Interviews}

H. Palahuddin, Chairman PW Muhammadiyah, NTB

Husnul Khatari (Prominent Muslim of Bebidas, Lombok)

TGH Taqiyuddin, Chairman of PWNU, NTB

TGH. Jamiludin, Secretary of IAIH Nahdlatul Wathan, NTB

TGH. Sahdan Ilyas, Chairman of FKUB, NTB. 